\title{
FAST AND SELECTIVE HPLC-DAD METHOD FOR DETERMINATION OF PHOLCODINE AND RELATED SUBSTANCES
}

\author{
Ana Petkovska ${ }^{1,2}$, Hristina Babunovska ${ }^{1}$, Marina Stefova ${ }^{2 *}$ \\ ${ }^{1}$ Pharmaceutical Quality Control, Alkaloid AD Skopje, \\ Blvd. Aleksandar Makedonski 12, 1000 Skopje, Republic of Macedonia \\ ${ }^{2}$ Institute of Chemistry, Faculty of Natural Sciences and Mathematics, \\ Ss. Cyril and Methodius University, Arhimedova 5, 1000 Skopje, \\ Republic of Macedonia \\ *e-mail: marinaiv@pmf.ukim.mk
}

\begin{abstract}
Quality control of pharmaceuticals requires development of fast, efficient and reliable methods for determination of active compounds as well as known and very often unknown impurities within defined concentration ranges. In this work, a simple and rapid HPLC-UV-DAD method for identification and quantification of pholcodine process related impurities and some degradation products was developed and validated. Pholcodine and its five structural analogues such as morphine, codeine, thebaine, oripavine, and papaverine were separated in less than 10 minutes using reversed phase LiChrospher C-8 column. For optimal chromatographic performance with reproducible retention times, gradient elution with $2 \%$ ammonium hydroxide in water and acetonitrile was used. The method was validated by establishing its selectivity, specifity, sensitivity, linearity, intra- and inter-day precision and robustness. All tested parameters confirmed that the method is suitable for determination of pholcodine and its five impurities in pharmaceutical drug samples. The results obtained from real sample analysis give support to the suitability of the proposed method for the purpose of quality control.
\end{abstract}

Keywords: pholcodine; impurities; validation; HPLC-DAD; opium alkaloids

\section{HPLC-DAD БРЗ И СЕЛЕКТИВЕН МЕТОД ЗА ОПРЕДЕЛУВАњЕ НА ФОЛКОДИН И СРОДНИ СУПСТАНЦИ}

\begin{abstract}
При контрола на квалитетот на фармацевтски активни супстанци се потребни брзи, ефикасни и сигурни методи за определување на активните супстанци, како и на познати, а често и на непознати загадувачи во определен концентрациски опсег. Во овој труд е прикажан развој и валидација на едноставен и брз HPLC-UV-DAD метод за идентификација и квантификација на онечистувања кои потекнуваат од процесот на синтеза на фолкодин. Фолкодинот и пет од неговите структурни аналози: морфин, кодеин, тебаин, орипавин и папаверин, беа издвоени за помалку од 10 минути со помош на реверзно фазна колона од типот LiChrospher C-8. Оптимално разделување и репродуцибилни ретенциони времиња беа постигнати со градиентно елуирање со $2 \%$ амониум- хидроксид во вода и ацетонитрил. Методот беше валидиран преку тестирање на селективноста, специфичноста, осетливоста, линеарноста, прецизноста и робусноста. Сите тестирани параметри потврдуваат дека методот е соодветен за определување на фолкодин и пет негови онечистувања во фармацевтски суровини при контрола на квалитетот во индустриски процеси. Како потврда на погодноста на предложениот метод, тој е применет за анализа на реални примероци.
\end{abstract}

Клучни зборови: фолкодин; загадување, валидација; HPLC-DAD; опојни алкалоиди. 


\section{INTRODUCTION}

Quality, safety and effectiveness of drugs are essential concerns in pharmaceutical industry. Effective monitoring and controlling of impurities are crucial for assuring the quality and safety of a drug. Thus, the analytical characterization of drug impurities represents irreplaceable tool in modern pharmaceutical examinations. Nowadays, analytical activities are even more employed to discover either impurities originating from degradation or related products that can be formed by inprocess reactions. This indicates that the purity of the final product should always be supported by additional purity profiling of the related substances based on the materials used in its preparation [1].

Although drug impurities originate from different sources and stages of the synthesis and preparation of pharmaceutical dosage forms, a precise differentiation between the process-related impurities and degradation products cannot always be achieved. Since the presence of the majority of impurities is attributed to the synthetic pathways of the manufacturing process, it is likely that the same product form different sources may give rise to different impurities due to a variety of chemical reactions in the process. Therefore, continuous analytical recognition of the problematic compounds in the starting pharmaceutical ingredients has been recommended as the first step towards characterization of the purity of the drugs [2]. The most reliable scientific approach to characterize the quality of a bulk drug is to determine its purity by means of chromatographic techniques in contradiction to the characterization based on nonspecific methods supported by determination of physical constants, limit tests and colour reactions [3].

Pholcodine or 7,8-didehydro-4,5 $\alpha$-epoxy17-methyl-3-[2-(morpholin-4-yl)ethoxy] morphinan-6 $\alpha-\mathrm{ol}$ ) (Figure 1) is a semisynthetic opioid antitussive agent. It is synthesized by treating an aqueous solution of morphine with an equivalent amount of sodium hydroxide or other appropriate base followed by addition of chloroethylmorpholine hydrochloride [4]. Opium alkaloids are derived from the latex of the seed capsule of the opium poppy Papaver somniferum L. [5]. There is a great probability for the presence of impurities in purified alkaloids since plant materials are imported from various parts of the world and therefore the content of alkaloids might vary considerably depending on the origin [6]. Since pholcodine is a semisynthetic drug, impurities may come from impurities present in the morphine starting material as well as from the manufacturing process itself.

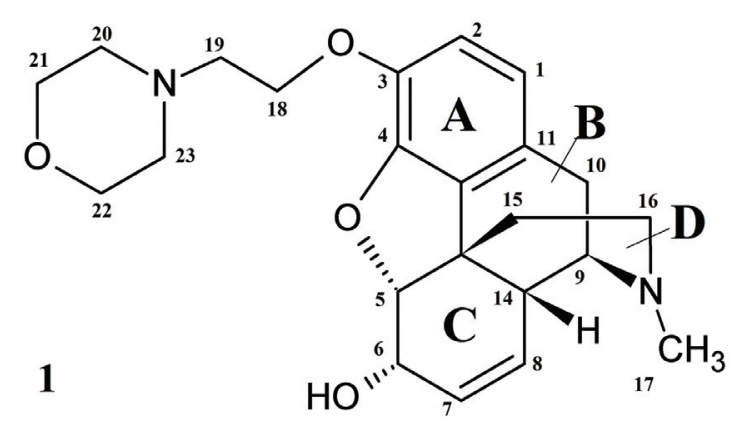

Fig. 1. Structural formula of pholcodine (7,8-didehydro-4,5 $\alpha$-epoxy-17-methyl-3-[2- (morpholin4-yl) ethoxy] morphinan-6 $\alpha$-ol)

Because the morphine impurities are controlled at a low level, as described in the current European Pharmacopoeia [2], morphine solely remains potential impurity in the starting material. Manufacturing impurities of pholcodine may arise during synthesis from side reactions of chloroethylmorpholine with other sites in the morphine molecule [4]. In addition, possible in-process impurities of pholcodine arising from the starting plant material can also be the following morphine analogues: codeine, thebaine, oripavine and papaverine (Figure $2)$. Morphine (7,8-didehydro-4,5 $\alpha$-epoxy-17methylmorphinan-3,6 $\alpha$-diol,), and codeine (7 ,8-didehydro-4,5 $\alpha$-epoxy-3-methoxy-17-me thylmorphinan- $6 \alpha$-ol,) can also be identified as pholcodine degradation products. Despite previously mentioned related impurities, current European Pharmacopoeia recognizes the 
<smiles>CN1CC[C@]23c4c(ccc(O)c4[C@H]4O[C@@H]2C=C[C@@H]4O)C[C@H]3C1</smiles>

Morphine $((5 \alpha, 6 \alpha)$-7,8-didehydro4,5-epoxy-17-methylmorphinan-3,6-diol)<smiles>COC1=CC=C2C3CC[C@H]1Oc1c(OC)ccc(c13)[C@]21CCN1C</smiles>

Thebaine (6,7,8,14-tetradehydro-4,5 $\alpha$-epoxy-3,6dimethoxy-17-methylmorphinan)<smiles></smiles>

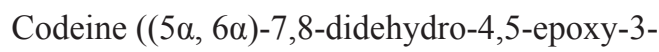
methoxy-17-methylmorphinan-6-ol)<smiles>CO[C@H]1C=CC2=C[C@H]3Cc4ccc(O)c5c4[C@@]2(CCN3C)[C@@H]1O5</smiles>

Oripavine (6,7,8,14-tetradehydro-4,5 $\alpha$-epoxy6-methoxy-17-methylmorphinan-3-ol)<smiles>COc1ccc(Cc2nccc3cc(OC)c(OC)cc23)cc1OC</smiles>

Papaverine (1-(3,4-dimethoxybenzyl)-6,7dimethoxyisoquinoline)

Fig. 2. Structural formulae of pholcodine related substances.

following other impurities also listed in literature (not discussed here): pholcodine $N$-oxide ((17RS)-7,8-didehydro-4,5 $\alpha$-epoxy-17-methyl3-[2-(morpholin-4-yl)ethoxy]morphinan-6 $\alpha$-ol 17-oxide), pholcodine $N^{\prime}$-oxide (7,8-didehydro4,5 $\alpha$-epoxy-17-methyl-3-[2-(4-oxidomorpholin4-io)ethoxy]morphinan-6 $\alpha$-ol), pholcodine $N$, $N^{\prime}$-dioxide ((17RS)-7,8-didehydro-4,5 $\alpha$-epoxy- 17-methyl-3-[2-(4-oxidomorpholin-4-io)ethoxy]morphinan-6 $\alpha$-ol 17-oxide).

The number of published chromatographic analytical methods for identification and quantification of pholcodine process related impurities (and degradation products) is very limited. Namely, Denk et al. [4] have developed a quantitative HPLC method for separation and 
determination of structurally related manufacturing impurities of pholcodine. Previously, the European Pharmacopoeia has suggested a TLC method for pholcodine purity profiling and at present it recommends that pholcodine impurities profiling should be tested with long run time HPLC method using tetrahydrofuran (THF) in the mobile phase. However, different methods for characterization and identification of pholcodine drug as a morphine analogue extracted from complex matrices have been developed and used for other purposes than quality control of pharmaceuticals $[7,8]$. All previously published methods demand long run times, toxic and complex mobile phases and were not capable to determine some of the previously mentioned impurities.

In this work, pholcodine bulk drug substance was examined with simple, effective and very fast HPLC-UV-DAD method to separate, identify and quantify pholcodine and five of its impurities: morphine, codeine, thebaine, oripavine, and papaverine. This analytical procedure was validated to demonstrate the specifity, selectivity, accuracy, precision, limit of detection and quantification, linearity, range, interferences and robustness. The method was tested for additional peak tailing, peak resolution and analytes recoveries according to $\mathrm{ICH}$ guidelines [9].

\section{EXPERIMENTAL}

\subsection{Materials}

Different batches of pholcodine monohydrate bulk drug substance were supplied from the manufacturer Alkaloid A.D. Skopje, Republic of Macedonia, as well as substances used as working standards (morphine hydrochloride trihydrate, codeine phosphate sesquihydrate, thebaine, oripavine, and papaverine). HPLC columns, acetonitrile (HPLC grade), ammonium hydroxide, redistilled water and formic acid were purchased from Merck, Darmstadt, Germany. Certified reference standards of pholcodine, codeine hydrochloride dihydrate and morphine hydrochloride trihydrate used for additional confirmation of obtained results were supplied from European Pharmacopoeia.

\subsection{Instrumentation}

HPLC separations were carried out with Agilent 1200 chromatographic system composed of autosampler, quaternary pump, column oven and UV-VIS diode array detector.

\subsection{Method}

Pholcodine and its five structural analogues were separated using reversed phase LiChrospher C-8 (250 x $4 \mathrm{~mm}$ column, $5 \mu \mathrm{m})$ heated at $35^{\circ} \mathrm{C}$. For optimal performance, a gradient mobile phase consisting of both $2 \%(V / V)$ $\mathrm{NH}_{4} \mathrm{OH}$ in water (adjusted to $\mathrm{pH}=3.2$ with formic acid) and acetonitrile was used. Separation was performed by gradient elution starting with $80 \%$ aqueous solution and reaching $100 \%$ acetonitrile at the tenth minute. Elution was monitored in the whole UV-VIS range and peaks were detected at a wavelength of $283 \mathrm{~nm}$.

The total run time, including 2 minutes equilibration time, was 12 minutes. The flow rate was $1 \mathrm{ml} / \mathrm{min}$, and the injection volume was 30 $\mu 1$.

\subsection{Solutions for chromatography}

Solutions used for chromatography such as $25 \%$ ammonium hydroxide, formic acid and acetonitrile were purchased from Merck. Mobile phase preparation and solvent mixture preparation are described in sections 2.3 and 3.1.

\section{Test solution preparation}

Sample preparation of the tested batches of pholcodine monohydrate produced as bulk substance in Alkaloid AD Skopje was made so 
that a final concentration of pholcodine in the test solution was $1000 \mu \mathrm{g} / \mathrm{ml}$. Samples were dissolved in $20 \%$ in acetonitrile in water.

\section{Standard solutions preparation}

In order to prepare standard series solutions, stock solutions with concentration $1000 \mu \mathrm{g} / \mathrm{ml}$ were prepared of every individual alkaloid. Also, one stock solution was prepared as a mixture of all six analytes. Different sequences of dilutions of these stock solutions were made for different calibration level standards and validation standards. All samples were dissolved in 20\% acetonitrile in water.

Pure pholcodine substance standard solution was made by measuring $20.00 \mathrm{mg}$ of pholcodine and dissolving in $10 \mathrm{ml}$ of solvent by sonication for 10 minutes and then filled to $20 \mathrm{ml}$ with solvent mixture. Similarly, in order to achieve the same concentration of pure alkaloids in stock solutions: $20.90 \mathrm{mg}$ of pholcodine monohydrate; $26.30 \mathrm{mg}$ morphine hydrochloride trihydrate; $26.94 \mathrm{mg}$ codeine phosphate sesquihydrate and $24.88 \mathrm{mg}$ of codeine hydrochloride trihydrate were weighed for preparation of the respective standard solutions.

\section{RESULTS AND DISCUSSION}

The recommended methods for pholcodine, such as the one described in the European Pharmacopoeia, prescribe the use of tetrahydrofuran (THF) [2], whereas methods for morphine and codeine suggest the use of ion-pairing mobile phases [2]. So, in this work, HPLC method was developed in order to save time and avoid troublesome reagents (THF) and ion pairing mobile phases, which can strongly bond to the reversed phase column packing. So, this method with simple and non-demanding mobile phase prolongs column lifetime. Sample and solvent mixtures preparation such as mobile phase preparation were also simplified. Moreover, efficient chromatographic separation with narrow and symmetrical peaks was achieved. The main challenge of this study was to obtain a selective HPLC-UV-DAD method with reduced possibility of problematic chromatographic conditions, long run times and poor performance. The principal characteristics of the proposed HPLC-UV-DAD method are summarized in the following tables and figures.

\subsection{Method development}

The first attempt to satisfy the above-mentioned method features were to optimise the separation with isocratic elution starting with $80 \%$ aqueous mobile phase $\left(2 \% \mathrm{NH}_{4} \mathrm{OH}\right.$ in water, $V / V)$. The first peak due to pholcodine appeared at around $15 \mathrm{~min}$ and all other peaks due to its related compounds in time range from 30 to $70 \mathrm{~min}$. The long retention times, poor peak symmetry and low resolution were attributed to the low amount of organic solvent in the mobile phase. Therefore, gradient elution to $100 \%$ of organic solvent was applied resulting in shorter retention times for the more retained peaks.

Afterwards, the influence of the $\mathrm{pH}$ of aqueous mobile phase on separation and peak shape was investigated by varying the $\mathrm{pH}$ of the aqueous phase between 2.5 and 3.5. It was noticed that when $\mathrm{pH}$ of the aqueous mobile phase was adjusted to 3.0 (described in 2.3. Method), the injected mixture of pholcodine and the five related compounds (morphine, codeine, thebaine, oripavine and papaverine) resulted in the peak appearance following the above sequence. However, as it can be seen in the chromatogram in Figure 3a, the peak of pholcodine at this $\mathrm{pH}$ level showed poor symmetry (1.9) and unsatisfactory baseline separation from morphine $\left(R_{\mathrm{s}}=1.35\right)$. Significant difference in the separation and peak symmetry, particularly for the peak due to pholcodine was achieved by slightly increasing $\mathrm{pH}$ to 3.2 (Figure $3 b)$.

Additionally, variations of other parameters were tested to achieve better separation and peak shape such as the content of ammonia in aqueous mobile phase (0.5-3.0\%). Addition of $2 \%$ ammonium hydroxide in water was most favourable for 
obtaining narrow peaks. Also, the solubility of the analytes was examined: standards were diluted primarily in acetonitrile, but the peaks showed best shape when the analytes were diluted in the mobile phase $(80 \%$ of $2 \%$ aqueous ammonium solution and $20 \%$ of acetonitrile $(V / V)$.

Column temperature also affected retention and separation. It was noticed that at temperature of $25^{\circ} \mathrm{C}$, low peak symmetry was obtained whereas at higher temperatures $\left(45^{\circ} \mathrm{C}\right)$, peaks from morphine, codeine and pholcodine coeluted. For achieving resolution of all analytes, shorter retention times and symmetrical peaks, the temperature of $35^{\circ} \mathrm{C}$ was selected as optimal.

Since this is a method for screening of pholcodine impurities, in order to optimize a good performing method for quality control purposes, gradient elution (from $20 \%$ to $100 \%$ acetonitrile in $10 \mathrm{~min}$ ), $2 \%$ ammonia in the mobile phase and $\mathrm{pH}$ adjusted to 3.2 with formic acid, and column temperature of $35^{\circ} \mathrm{C}$ were selected as optimal conditions.

\subsection{Method validation}

\section{Identification}

For the purpose of identification of impurities, stock solutions made from the six standard

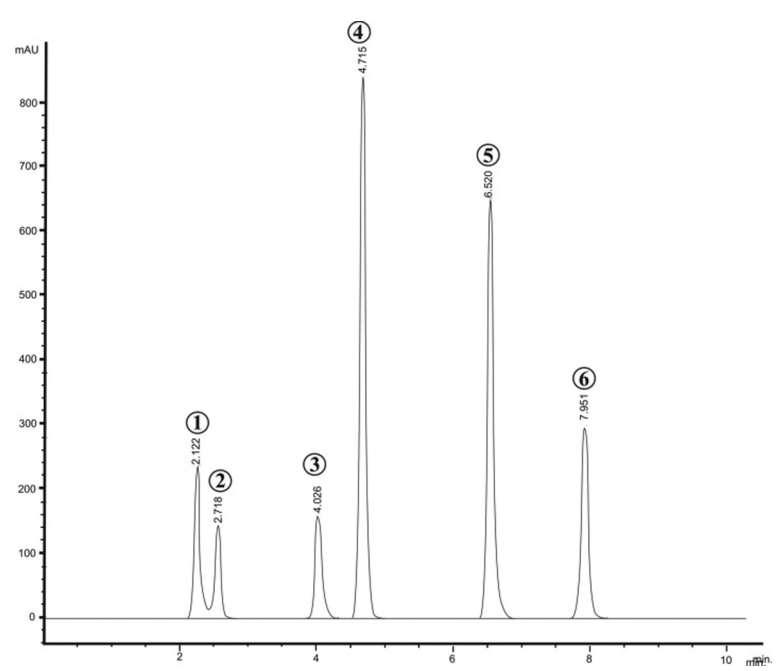

a) substances in concentration of $1000 \mu \mathrm{g} / \mathrm{ml}$ were tested. At first, all standard solutions were separately injected into the column to achieve specific retention times for each analyte (Table 1). Also, certified reference standard for pholcodine, codeine and morphine were used. For confirmation, all analytes' spectra collected by UV-DAD were compared to the reference spectra and absorbance maxima (specific absorbance) of these alkaloids from the Clark's analysis of drugs and poisons [4].

\section{Selectivity and specificity}

A mixture of the mobile phases ( $80: 20$, $2 \%$ ammonia in water : acetonitrile, $V / V)$ used as a solvent was injected into the chromatographic system as a test for selectivity. The chromatograms obtained showed no interference peaks (Figure 3b).

To assure the ICH criteria for specificity, the tested standard solutions used for identification were injected into the system six times. Besides collected spectra and recognized retention times, the relative response factors and relative retention times with respect to pholcodine were calculated. The principal peak of pholcodine appeared at retention time of $2.44 \mathrm{~min}$. Other alkaloids were resolved at retention times given in Table 1, Figure

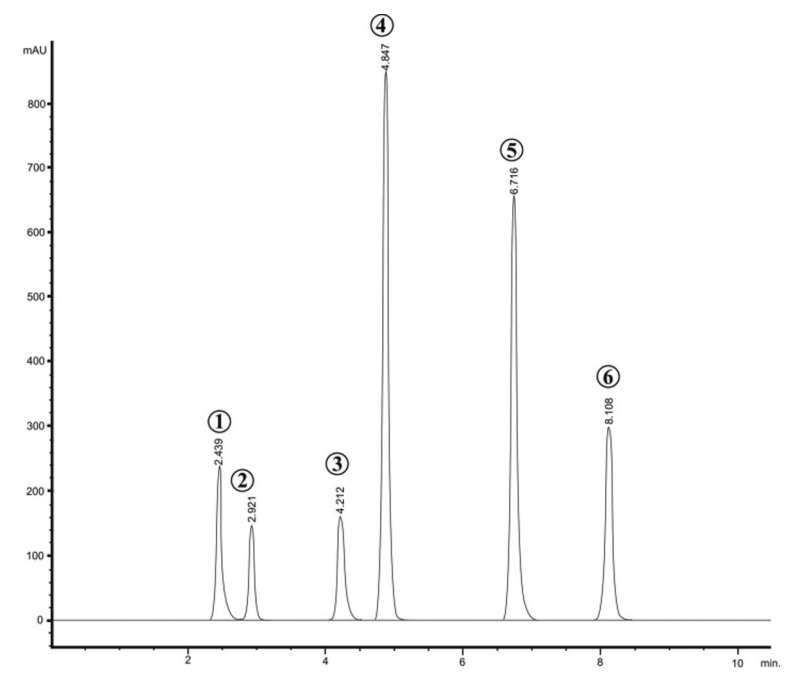

b)

Fig. 3. Chromatograms of pholcodine and related impurities (at $283 \mathrm{~nm}$ ): a) incomplete separation of pholcodine from morphine with mobile phase with $\mathrm{pH} 3.0$; b) baseline separation of pholcodine from morphine with mobile phase with pH 3.2. Peak numbering: 1. Pholcodine, 2.Morphine, 3. Codeine,

4. Thebaine, 5. Oripavine, 6. Papaverine 
3b. Additionally, mixtures of the six analytes were again injected into the column within six repetitions. It was shown that no interferences between the analytes in the mixture occurred indicating that they can be successfully determined either as individual compounds or in mixtures. The obtained results satisfied the recommended method specificity and selectivity [9].

\section{Accuracy and precision}

Mixtures of standard stock solutions were prepared to achieve pharmacopoeia rec- ommended concentrations of the main component, pholcodine, and the possible impurities in three concentration levels: $1.0 \mu \mathrm{g} / \mathrm{ml}$, $10.0 \mu \mathrm{g} / \mathrm{ml}$ and $1000.0 \mu \mathrm{g} / \mathrm{ml}$. The first two concentration levels represent standard dilutions from the test sample and the third level represents the working concentration level of the test sample, recommended by the current European Pharmacopoeia method [2].

Accuracy was determined as the average difference (in percentage) between found and theoretical concentration of validation samples at three different concentration levels for each

$\mathrm{T}$ a b 1 e 1

Retention times, relative retention times with respect to pholcodine and resolution for each of the six analytes obtained with the optimized HPLC method (corresponding to Figure 3b).

\begin{tabular}{lccc}
\hline \hline \multicolumn{1}{c}{ Peak name } & Retention time/min & $\begin{array}{c}\text { Relative retention time with } \\
\text { regard to pholcodine }\end{array}$ & $\begin{array}{c}\text { Resolution between } \\
\text { adjacent peaks }\end{array}$ \\
\hline Pholcodine & 2.44 & 1.00 & - \\
Morphine & 2.91 & 1.19 & 2.50 \\
Codeine & 4.21 & 1.73 & 6.32 \\
Thebaine & 4.85 & 1.99 & 3.01 \\
Oripavine & 6.72 & 2.75 & 8.42 \\
Papaverine & 8.11 & 3.32 & 3.21 \\
\hline \hline
\end{tabular}

T a b l e 2

Intra-day precision (repeatability) and intra-day accuracy

\begin{tabular}{|c|c|c|c|c|c|c|c|c|c|}
\hline \multirow[b]{2}{*}{ Compound } & \multicolumn{3}{|c|}{$\begin{array}{l}\text { Theoretical concentration } \\
1.0 \mu \mathrm{g} / \mathrm{ml}\end{array}$} & \multicolumn{3}{|c|}{$\begin{array}{l}\text { Theoretical concentration } \\
10.0 \mu \mathrm{g} / \mathrm{ml}\end{array}$} & \multicolumn{3}{|c|}{$\begin{array}{l}\text { Theoretical concentration } \\
1000.0 \mu \mathrm{g} / \mathrm{ml}\end{array}$} \\
\hline & $\begin{array}{c}\text { Found } \\
\text { mean } \\
(\mu \mathrm{g} / \mathrm{ml})\end{array}$ & $\begin{array}{l}\text { RSD } \\
(\%)\end{array}$ & $\begin{array}{l}\text { Relative } \\
\text { error }(\%)\end{array}$ & $\begin{array}{l}\text { Found } \\
\text { mean } \\
(\mu \mathrm{g} / \mathrm{ml})\end{array}$ & $\begin{array}{l}\text { RSD } \\
(\%)\end{array}$ & $\begin{array}{l}\text { Relative } \\
\text { error }(\%)\end{array}$ & $\begin{array}{c}\text { Found } \\
\text { mean } \\
(\mu \mathrm{g} / \mathrm{ml})\end{array}$ & $\begin{array}{l}\text { RSD } \\
(\%)\end{array}$ & $\begin{array}{l}\text { Rela- } \\
\text { tive } \\
\text { error } \\
(\%)\end{array}$ \\
\hline Pholcodine & 0.9 & -2.00 & 1.14 & 9.4 & 0.66 & -6.00 & 999.9 & 0.25 & -1.00 \\
\hline Morphine & 0.9 & -1.00 & 1.03 & 9.9 & 0.76 & -1.00 & 1000.2 & 0.55 & 2.00 \\
\hline Codeine & 1.0 & 1.00 & 1.66 & 9.7 & 1.41 & -3.00 & 1000.3 & 0.15 & 2.50 \\
\hline Thebaine & 1.0 & -0.10 & 0.71 & 10.5 & 0.18 & 5.00 & 999.8 & 0.40 & -2.00 \\
\hline Oripavine & 1.0 & 2.00 & 0.19 & 10.7 & 1.36 & 7.00 & 999.7 & 0.65 & -2.90 \\
\hline Papaverine & 1.0 & 5.00 & 0.89 & 9.9 & 0.58 & -1.00 & 1000.7 & 0.59 & 7.00 \\
\hline
\end{tabular}


of the 6 analytes. Intra-day accuracy was determined as relative error of the observed concentrations $(1.0 \mu \mathrm{g} / \mathrm{ml}, 10.0 \mu \mathrm{g} / \mathrm{ml}$ and 1000.0 $\mu \mathrm{g} / \mathrm{ml}$ ) of six replicate analyses conducted for the validation mixtures. Average results from intra-day precision are presented in Table 2 . Inter-day accuracy was determined as relative error, as well, obtained by comparison of found concentrations in the three concentration levels of validation standard solutions mixtures to theoretical ones. The results for inter-day ac- curacy obtained by 10 successive analyses of the three concentration levels during 10 days are presented in Table 3.

Precision was considered as repeatability (intra-day precision), and reproducibility (inter-day precision). Relative standard deviations from six successive analyses of the three concentration levels during one day are presented in Table 2, and results confirming reproducibility of the six analytes are presented in Table 3.

$\mathrm{T}$ a b 1 e 3

Inter-day precision (repeatability) and intra-day accuracy

\begin{tabular}{lccccccccc}
\hline \hline & \multicolumn{2}{c}{$\begin{array}{c}\text { Theoretical concentration } \\
1.0 \mu \mathrm{g} / \mathrm{ml}\end{array}$} & \multicolumn{2}{c}{$\begin{array}{c}\text { Theoretical concentration } \\
10.0 \mu \mathrm{g} / \mathrm{ml}\end{array}$} & \multicolumn{3}{c}{$\begin{array}{c}\text { Theoretical concentration } \\
1000.0 \mu \mathrm{g} / \mathrm{mL}\end{array}$} \\
\hline \multirow{3}{*}{ Compound } & $\begin{array}{c}\text { Found } \\
\text { mean } \\
(\mu \mathrm{g} / \mathrm{ml})\end{array}$ & $\begin{array}{c}\text { RSD } \\
(\%)\end{array}$ & $\begin{array}{c}\text { Relative } \\
\text { error }(\%)\end{array}$ & $\begin{array}{c}\text { Found } \\
\text { mean } \\
(\mu \mathrm{g} / \mathrm{ml})\end{array}$ & $\begin{array}{c}\text { RSD } \\
(\%)\end{array}$ & $\begin{array}{c}\text { Relative } \\
\text { error } \\
(\%)\end{array}$ & $\begin{array}{c}\text { Found } \\
\text { mean } \\
(\mu \mathrm{g} / \mathrm{ml})\end{array}$ & $\begin{array}{c}\text { RSD } \\
(\%)\end{array}$ & $\begin{array}{c}\text { Relative } \\
\text { error }(\%)\end{array}$ \\
\hline Pholcodine & 0.9 & 1.29 & -3.00 & 9.7 & 1.12 & -2.33 & 999.3 & 1.25 & -5.00 \\
Morphine & 0.9 & 1.33 & -8.00 & 9.9 & 0.22 & -0.99 & 1000.1 & 1.55 & 2.50 \\
Codeine & 1.0 & 1.15 & 2.50 & 9.7 & 1.45 & -4.05 & 999.1 & 1.45 & 6.50 \\
Thebaine & 0.9 & 0.95 & -0.70 & 10.3 & 0.99 & 2.11 & 999.6 & 0.94 & -1.80 \\
Oripavine & 1.0 & 0.24 & 6.50 & 10.1 & 1.25 & 3.54 & 999.2 & 0.52 & -2.70 \\
Papaverine & 1.0 & 1.77 & 1.10 & 9.6 & 0.65 & -0.99 & 999.1 & 0.28 & 2.48 \\
\hline \hline
\end{tabular}

The same calculations were carried out for preparation of the standard solution before it was diluted to prepare standard solution $10.0 \mu \mathrm{g} / \mathrm{ml}$ in order to control the precision of the analyst, as part of the parameter intermediate precision (results not shown). Values for concentrations presented in Tables 2 and 3 were back calculated from calibration curves discussed in the next section. The same procedure was made for inter-day precision where suitable precision and accuracy was confirmed. Presented results comply with the criterion given by $\mathrm{ICH}$ : relative standard deviation not higher than $10 \%$.

\section{Limit of detection (LOD) and limit of quantification (LOQ)}

Sensitivity of the method was determined by HPLC-UV-DAD analyses of blank samples and validation standards with low and high concentrations for all analytes of interest shown in the chromatogram (Figure $3 b$ ). According to $\mathrm{ICH}$ guidelines the range of the calibration curve should be considered from the reporting levels of impurity, which is $0.1 \%$ (corresponding to $1.0 \mu \mathrm{g} / \mathrm{ml}$ ) to $120 \%$ of the specification. Calibration curves are discussed in the next section. Limit of detection was determined directly for the principal peak of pholcodine by 10 injections using half of pholcodine concentration $(0.5 \mu \mathrm{g} /$ $\mathrm{ml}$ ) from the recommended diluted standard solution $(1.0 \mu \mathrm{g} / \mathrm{ml})$. By the injections of the LOD standard, it was registered that RSD of the retention time was $0.23 \%$ and the one of the peak area $2.06 \%$. This concentration was back calculated from the calibration curve for low concentrations described in the next section as average concentration of $0.5 \mu \mathrm{g} /$ $\mathrm{ml}$. The relative error was $18.22 \%$ being be- 
Ta b l e 4

$L O D$ and LOQ for pholcodine and related compounds $(n=10)$

\begin{tabular}{ccccccc}
\hline \hline Name & $\begin{array}{c}\text { LOD }( \\
\mu \mathrm{g} / \mathrm{mL})\end{array}$ & $\begin{array}{c}\text { RSD } \\
(\%)\end{array}$ & $\begin{array}{c}\text { Relative error } \\
(\%)\end{array}$ & $\begin{array}{c}\text { LOQ } \\
(\mu \mathrm{g} / \mathrm{mL})\end{array}$ & $\begin{array}{c}\text { RSD } \\
(\%)\end{array}$ & $\begin{array}{c}\text { Relative error } \\
(\%)\end{array}$ \\
\hline Pholcodine & 0.5 & 5.18 & 18.22 & 1.0 & 5.60 & 11.60 \\
Morphine & 0.5 & 4.99 & 16.99 & 1.0 & 2.62 & 10.62 \\
Codeine & 0.5 & 5.17 & 11.33 & 1.0 & 3.84 & 9.84 \\
Thebaine & 0.5 & 6.99 & 12.51 & 1.0 & 1.25 & 11.25 \\
Oripavine & 0.5 & 7.72 & 17.24 & 1.0 & 5.55 & 15.55 \\
Papaverine & 0.5 & 2.29 & 10.11 & 1.0 & 2.43 & 12.43 \\
\hline \hline
\end{tabular}

low the one allowed for the limit of detection $(20 \%)$.

LOQ was determined for the concentration of $1.0 \mu \mathrm{g} / \mathrm{ml}$ showing the relative error of $11.60 \%$ for ten injections.

LOD and LOQ were calculated according to the approach based on the standard deviation of the response [9].

\section{Linearity and range}

Calibration curve for pholcodine standard solutions in a wide concentration range with concentrations of $1.0 ; 5.0 ; 200 ; 400 ; 650 ; 900$; $1000 ; 1500$ and $2000 \mu \mathrm{g} / \mathrm{ml}$ was firstly made showing good correlation with $\mathrm{R}^{2}$ of 0.9938 . All other calibration curve points were constructed using five points achieving suitable correlation coefficients (Table 5). All calibration curves show satisfactory correlation higher than 0.99 . In all calibration curves zero point was included.

\section{System suitability and robustness}

Testing the suitability of the system as an integral part of the analytical procedure evaluates the performances of the system itself and the suitability of the analytical method within the system. The influence of slight variation in injection volume $(20-50 \mu \mathrm{l})$, flow rate $(0.5-2.0$ $\mathrm{mL} / \mathrm{min})$ and column temperature $\left(25-40^{\circ} \mathrm{C}\right)$ were tested for demonstration of intermediary precision by injecting three replicates of the mixture of the six standard substances. Both, retention times and peak areas, during variations

T a b l e 5

Correlation coefficients and calibration curve equations for each of the six analytes $(y$ - peak area; $x$-concentration in $\mu \mathrm{g} / \mathrm{ml})$

\begin{tabular}{lcc}
\hline \hline \multicolumn{1}{c}{ Name } & Calibration curve equation & $R^{2}$ \\
\hline Pholcodine & $y=5653.38 x-0.5618$ & 0.9938 \\
Morphine & $y=10328.43 x-0.7056$ & 0.9970 \\
Codeine & $y=8024.29 x-0.4952$ & 0.9990 \\
Thebaine & $y=37832.86 x+7.7010$ & 0.9971 \\
Oripavine & $y=51836.15 x-3.7569$ & 0.9994 \\
Papaverine & $y=17055.77 x+1.2104$ & 0.9943 \\
\hline \hline
\end{tabular}


T a b l e 6

Robustness of the method and system suitability results

\begin{tabular}{lccccc}
\hline \hline \multirow{2}{*}{ Peak name } & $\begin{array}{c}\text { Inj. volume: } 50 \mu 1 \\
\text { Relative error }(\%)\end{array}$ & $\begin{array}{c}\text { Temperature: } 40^{\circ} \mathrm{C} \\
\text { Relative error }(\%)\end{array}$ & $\begin{array}{c}\text { Flow: } 1.5 \mathrm{ml} / \mathrm{min} \\
\text { Relative error }(\%)\end{array}$ & $\begin{array}{c}\text { Peak symmetry } \\
\text { at } 1.5 \mathrm{ml} / \mathrm{min}\end{array}$ & $\begin{array}{c}\text { Resolution } \\
\text { at } 1.5 \mathrm{ml} / \mathrm{min}\end{array}$ \\
\hline Pholcodine & 0.15 & 0.12 & 2.22 & 0.95 & - \\
Morphine & 0.29 & -0.39 & 1.55 & 1.08 & 2.28 \\
Codeine & 0.12 & 0.22 & -4.22 & 0.99 & 6.09 \\
Thebaine & -0.11 & -1.17 & -2.87 & 1.21 & 2.71 \\
Oripavine & 0.55 & 1.55 & -2.25 & 1.28 & 8.59 \\
Papaverine & -0.09 & 2.15 & 1.35 & 1.27 & 3.55 \\
\hline \hline
\end{tabular}

of the mentioned parameters showed relative errors not larger than 5\%. Moreover, very good values regarding peak symmetry and resolution have been achieved for all 6 analytes. The criteria for peak symmetry with coefficients smaller than 1.5 and resolution between peaks not smaller than 2.0 were achieved even with substantial variations as demonstrated in Table 6 . The robustness of the method was tested for modification of injection volume, flow rate and column temperature. It was noticed that largest alteration due to the mentioned changes appeared in retention times. Relative error of the variation of the retention time was calculated for all analytes where both retention time and peak area showed relative error not higher than $5 \%$.

\subsection{METHOD APPLICATION}

After optimization and validation, the developed analytical method was tested on three different batches of pholcodine bulk substances. Results obtained with these analyses were evaluated according to the European Pharmacopoeia recommended limit ranges for testing pholcodine related substances: known impurities $<0.2 \%(2.0 \mu \mathrm{g} / \mathrm{ml})$, unspecified impurities $<0.1 \%(1.0 \mu \mathrm{g} / \mathrm{ml})$, total impurities $<0.7 \%$ (7.0 $\mu \mathrm{g} / \mathrm{ml})$ and disregard limit below $0.05 \%(0.5$ $\mu \mathrm{g} / \mathrm{ml})[2]$. The analyzed pholcodine impurities were found in less than $0.2 \%$ from total of codeine, morphine and oripavine (Table 7 ,
Figure 4). Unspecified impurities were found in concentration levels below disregard limit and therefore they are not shown. However, the values for the content of codeine, morphine and oripavine, although in the range around and below LOD of the method, were measured and calculated, which is in accordance with the recommendation of the European Pharmacopoeia for reporting of specified impurities.

Results achieved within this method for analyzing different batches of pholcodine bulk substances correspond to the results achieved in Pharmaceutical Quality Control of Alkaloid AD Skopje when the same batches were tested with a different analytical method.

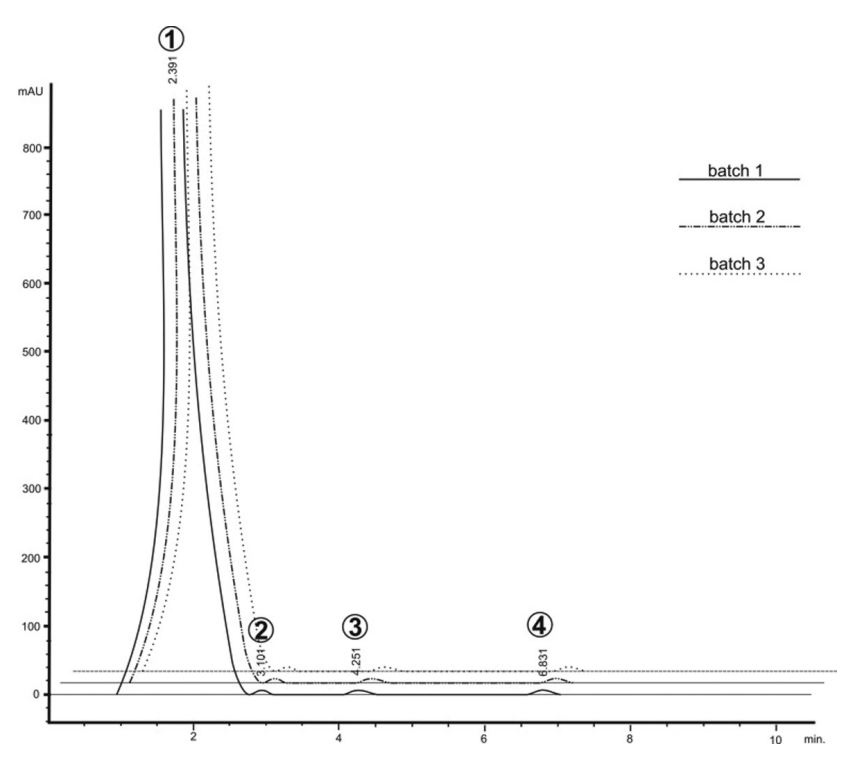

Fig. 4. Chromatograms obtained from real samples analyses of three different batches of pholcodine. Peaks: 1. Pholcodine, 2. Morphine, 3. Codeine, 4. Oripavine. 
T a b 1 e 7

Results obtained from real samples analysis (average of three measurements, $R S D<10 \%$ ).

\begin{tabular}{ccccccccccc}
\hline \multirow{2}{*}{$\begin{array}{c}\text { Pholcodine } \\
\text { batch number }\end{array}$} & $\%$ & $\mu \mathrm{g} / \mathrm{mL}$ & $\%$ & $\begin{array}{c}\mu \mathrm{\mu g} \\
\mathrm{mL}\end{array}$ & $\%$ & $\mu \mathrm{g} / \mathrm{mL}$ & $\%$ & $\mu \mathrm{g} / \mathrm{mL}$ & $\%$ & $\mu \mathrm{g} / \mathrm{mL}$ \\
\cline { 2 - 11 } & Pholcodine & \multicolumn{2}{c}{ Codeine } & \multicolumn{2}{c}{ Morphine } & \multicolumn{2}{c}{ Oripavine } & \multicolumn{2}{c}{ Total impurities } \\
\hline Batch 1 & 99.90 & 999.0 & 0.14 & 1.4 & 0.01 & 0.1 & 0.03 & 0.3 & 0.18 & 1.8 \\
Batch 2 & 99.32 & 993.2 & 0.08 & 0.8 & 0.09 & 0.9 & 0.01 & 0.1 & 0.18 & 1.8 \\
Batch 3 & 99.85 & 998.5 & 0.12 & 1.2 & 0.03 & 0.3 & 0.05 & 0.5 & 0.20 & 2.0 \\
\hline
\end{tabular}

This HPLC-UV-DAD method utilizing gradient elution for separation and quantification was created and applied for assay of the known six pholcodine impurities present in starting materials used as active pharmaceutical ingredients. It uses a common reversed stationary phase (C8) and simple and non-toxic mobile phases producing fast and efficient separation and short analysis time. The method was shown to be sufficiently selective and sensitive to detect the related compounds.

All validation parameters according to pharmaceutical guidelines and pharmacopoeias such as intra- and inter-day precision, selectivity, specifity, linearity, and robustness satisfy the established pharmacopoeia criteria.

The use of HPLC-UV-DAD for identification and measurement of drugs manage to elucidate even more questions raised by recently used HPLC methods for determination of pholcodine impurities. The developed method was found to be easily applicable and is expected to be widely used for the routine QC analysis in the pharmaceutical industry.

\section{REFERENCES}

[1] R. Nageswara Rao, V. Nagaraju, An overview of the recent trends in development of HPLC methods for determination of impurities in drugs, $J$. Pharm. Biomed.Anal. 33, 335-377 (2003).
[2] European Pharmacopoeia, Seventh Edition, Monograph Volume 2, EDQM of the Council of Europe, Strasburg, 2010, pp. 2674-2675.

[3] The United States Pharmacopoeia, XV, 15th revision, Mack Publishing Company, 1955, pp. 168187.

[4] O.M. Denk, A.I. Gray, G.G. Skleleren, D.G. Watson, Isolation and identification of three potential impurities of pholcodine bulk drug substance, J. Pharm. Pharmacol. 52, 819-829 (2000).

[5] Clark's analysis of drugs and poisons in pharmaceuticals, body fluids and postmortem materials, Third Edition, Monograph Volume 2, Pharmaceutical Press, 2004 pp. 845-1617.

[6] B. Rembrang, L. Krenn, B. Kopp, G. Buchbauer, A. Nikiforov, Principal content analysis of opium alkaloids contents for origin determination, Pharmazie 49,766-768 (1994).

[7] M. E. Bosh, A.R. Sanchez, F. Sanchez Rojas, C. Bosch Ojeda, Morphine and its metabolites: Analytical methodologies for its determination, J. Pharm. Biomed.Anal. 43, 799-815 (2007).

[8] M. Gergov, I. Ojanpera, E. Vuori, Simultaneous screening for 283 drugs in blood by liquid chromatography-ion spray tandem mass spectrometry with multiple reaction monitoring, J.Chromatogr. $B$ 795, 41-53 (2003).

[9] International Conference on Harmonisation of Technical Requirements for Registration of Pharmaceuticals of Human Use, Q2(R1): Validation of Analytical Methods: Text and Methodology, November (2005). 
